\title{
An essay in disappointment: the Aboriginal-Jewish relationship ${ }^{1}$
}

\author{
Colin Tatz
}

One can make much of the parallels and metaphors in the Aboriginal and Jewish experiences, and a few writers have done so. Andrea Goldsmith talked about 'expulsion, massacre, genocide, eternal scapegoats', with 'Jews and black Australians being equally experienced' in such matters. ${ }^{2}$ Evan Zuesse, a lecturer in modern Jewish history, perceived 'a shared universe', 'an enormous commonality', especially in their historical experience, their rootedness in land, in the centuries of attempted assimilation. ${ }^{3}$ Djiniyini Gondarra, a Uniting Church minister in Darwin, saw a unity in nomadism, in spirituality, the dreaming, and what he calls 'ceremonics'. 4

But, beyond metaphor, is there a relationship between Aborigines and Jews? Should there be one? Yes, I would argue very strongly that there is and should be, given the moral imperatives incumbent on all Jews. The five chapters of the sayings and teachings of the Jewish Sages, often referred to as the Ethics of the Fathers, insist that there are certain moral duties involved in being a Jew. For example, tikkun olam is a mandate to Jews, wherever they may be, to try to heal, to mend, to repair a flawed world. In the first century of the Common Era, Hillel (the Elder) and Jesus (the Jew) after him, made that very plain.

This kind of moral imperative: was exemplified by a group of Aboriginal people after the night of 9 November 1938, 'Kristallnacht', which was to that point in time the most violent public display of antisemitism in German history. A Nazi-organised pogrom, the "Night of Broken Glass" changed Jews from being a stigmatised group into a 'minorité fatale'. At least 7500 Jewish businesses were destroyed, 191 synagogues were burned down, 26,000 Jews were taken to concentration camps and 91 were murdered. ${ }^{5}$ There was instant world reaction to this prelude to the Holocaust. And, in faraway Melbourne, the Australian Aborigines' League, with not a single Jewish member, passed a

1. This is a revised and reframed version of a chapter, 'Jews and Aborigines', originally published in Jews and Australian Politics, edited by Geoffrey Levey and Philip Mendes, Sussex Academic Press, 2005.

2. Goldsmith 1999: 13.

3. Zuesse 1992: 11-16.

4. Gondarra 1992: 20-3.

5. Tatz 2003: 49-58. 
resolution protesting against Germany's treatment of Jews, particularly after 'Kristallnacht'. More than that, they took their protest statement to the German Consulate, where they were denied entry. ${ }^{6}$

This unsolicited and spontaneous protest was revealed when Melbourne's Jewish Holocaust Centre recently dedicated a plaque in memory of this expression of solidarity. ${ }^{7}$ But have there been similar Jewish expressions of care about Aboriginal experiences? In spite of what may look like a contrived paradigm, we need to look, however briefly, at Jewish participation in the African-American fight for civil rights and in the anti-apartheid struggle in South Africa. Certainly, differing geographies and demographies were, and are, involved; but the issue here is to arrive at a judgment on the claims about heavy, even disproportionate, Jewish involvement in Aboriginal affairs. Further, these respective political climates also tell us something about the opportunities for, and limits to, activism in race relations.

\section{Jews and Mississippi}

Jews were heavily engaged in the American civil rights movement, beginning with their core membership in WE du Bois' National Association for the Advancement of Colored People in 1909. Jews participated in every major anti-racism organisation thereafter. The Anti-Defamation League of B'nai B'rith (ADL), founded in 1913, was based on fighting antisemitism and all other forms of racial prejudice, and even in today's poisoned relationships, discussed below, the ADL persists with a 'Blacks and Jews Conversation' program.

American civil rights politics was, and is, violent, even murderous. Several Jews were seriously injured in the Montgomery civil rights movement between 1954 and 1960 and two Jews were killed by the Ku Klux Klan in Mississippi in 1964. The involvement of Jewish students in what was called the New Left (race) politics was remarkable. About one-third of the students who went to Mississippi in 1964 were Jews, and between one-third and one-half of 3000 American campus radical activists were Jews. Many Jewish heads were cracked by Mayor Richard Daley and his police minions in the Chicago of 1968, and Jewish radicals became household names, as with Abbie Hoffman and Jerry Rubin, in the farcical Chicago Seven trial.

Why this extraordinary attention to the plight of black Americans? Percy Cohen argued that white supremacy policies and practices 'aroused a moral sense of obligation which some of these students had acquired from their parents and/or their teachers; and it gave their search for a moral commitment a direction to follow'. ${ }^{8}$ There were, of course, contextual factors that influenced both Jewish and non-Jewish student activism: the use of illegitimate violence against blacks in the southern states; guilt and sympathy arising from the conditions that led to black revolts in the north; the escalation of campus protests and the matter of free speech; increasing knowledge of the poverty that was pervasive in most of black America; the escalation of the war in Vietnam; and the concomitant growth of the Peace Movement.

6. Reported in the Melbourne Argus and the Age, 3 December 1938.

7. Australian Jewish News, 20 December 2002.

8. Cohen 1980: 16-35. 
The breakdown between Jews and African-Americans began in the late 1960s and early 1970s. In 1965, author James Baldwin urged the end of the special Jewish-Black relationship, not because he disliked Jews but because, with the growth of the Black Panthers and the Black Power movement in general, he foresaw an emerging antisemitism from his people. He was right, of course. It wasn't long before a serious antisemitism and an equally serious Jewish racism began to emerge. ${ }^{9}$ Some of it was ideological and political; much of it was plain economics, with senior Jewish educators seen as blocking the paths to promotion of black teachers. There was also the accusation against Jews of being 'slum landlords'. Black Islam was on its way to becoming a form of Radical Islam, preaching all manner of dire statements about, and treatments of, Jews.

It was an innocent Melbourne rabbinical student, Yankel Rosenbaum, who brought about the end of this hitherto close Black-Jewish relationship. In August 1990, a car in a Lubavitch motorcade in Crown Heights (New York) accidentally knocked over two black children, one of whom died. A private Hassidic ambulance service arrived, took away the by now surrounded and endangered driver, an act that left local African-Americans furious at this seeming preference for attending to white safety. A cry of 'Get the Jew!' led to the fatal stabbing of Yankel, who happened to be in the vicinity. With his murder and the ensuing three-day riot, Jewish-Black relations hit rock bottom.

\section{Jews and apartheid South Africa}

Even though Nelson Mandela 'found Jews to be more broad-minded than most whites on issues of race', 10 the majority of South African Jews went along with the apartheid system, prospered by it, voted for it, and condemned those of their sons and daughters who opposed it.

The Jewish Board of Deputies in Johannesburg was the last of the denominational institutions to condemn apartheid. Only in the early 1990s did 'organisational' Jews voice an opinion on a system that some Methodists had begun attacking even before World War II; by the 1950s, individual Anglicans, like Father Trevor Huddelston ${ }^{11}$ and later Bishop Ambrose Reeves, ${ }^{12}$ had become vociferous. Catholics, a small minority in South Africa and much discriminated against in the land of the Dutch Reformed Church (DRC), were articulate. Two prominent DRC theologians - Dr Beyers Naude and Professor Albert Geyser - lost their jobs for condemning apartheid as a blasphemy on Christianity. ${ }^{13}$

A number of Jews had fought within the system as members of parliament, jurists, journalists, unionists, medical practitioners, academics. Others joined what became banned illegal organisations, whether socialist or communist in ideology or just simply

\footnotetext{
9. Shlomo Katz (1969) edited a significant symposium, run by Midstream magazine, on both sides of this divide.

10. Mandela 2002: 101.

11. Huddleston 1956.

12. Reeves 1960.

13. Brockman 1994 and Bunting 1964.
} 
groups of men and women who sought some form of social justice in a society so manifestly unjust.

The infamous 'Treason Trial' began in December 1956 - ironically, in the old Pretoria Synagogue - and focused almost entirely on the 'subversive' nature of the Freedom Charter, a document calling for human rights, equal rights before the law, the right to work and security, and the right to share in the country's wealth. After many withdrawals of indictments, the trial ended in the unanimous acquittal of the remaining 28 accused in March 1961. Twenty-three whites were accused at the start, of whom 14 were Jews. Eight of the nine defence team were Jewish. Among others, five white people were indicted for sabotage at the 'Rivonia Trial' in 1964, and all were Jews. Over the years, dozens of individual Jews were involved, one way or another, in opposing that nightmare world of 'the South African way of life'.

What is of enormous significance is that at the height of those trials, the Jewish Board of Deputies - the roof body representing Jewish organisations and communities - and the editors of Jewish newspapers denounced those Jews as 'not being representative' of the Jewish community, and of not even belonging. They were branded as apostates. People like Joe Slovo, Julius First, Ruth First, Baruch Hirson, Rowley Arenstein, Denis Goldberg, Harold Wolpe, Arthur Goldreich, and James Kantor were, in a word, traitors to both a revered 'South African way of life' and to an ethical, upright Jewishness. They were seen as having deserted their Jewishness.

Gideon Shimoni has published a profound analysis of Jews in the apartheid years entitled Community and conscience. He examined individual and communal behaviour, concluding that 'although there is nothing in this record deserving of moral pride, neither does it warrant utter self-reproach'. This was, he declared, 'characteristic minoritygroup behaviour - a phenomenon of self-preservation, performed at the cost of moral righteousness'. ${ }^{14} \mathrm{My}$ judgment is harsher than Shimoni's, much stronger in condemnation of this loss of moral righteousness by the community leadership. But, I have to remind myself, this was a vigorously, vehemently antisemitic society - and an unceasingly violent one.

Not unsurprisingly, in the new 'Rainbow Country', Jewish organisations, writers, and journalists now proclaim the quintessential Jewishness of these traitors-turnedfolk-heroes. In his published interviews with 27 former activists, Immanuel Suttner welcomes them back, 'these worthy South Africans, socialists, communists or liberals', and yes, 'these worthy Jews'. ${ }^{15}$

There were different forces, factors, and motivations that led to such activism and such bravery. First, there was the gross, the blatant, and the hypocritical in South African life, in Jewish South African life, that cried out for some change. Second, there was an obvious dissonance between Jewish ideals and Jewish behaviour. Third, there was the haunting feeling that only by the thinnest of one's skin was a Jew considered white, and only just white enough, to enjoy legal, political, economic, and occasionally, social privilege in that antisemitic society. Fourth, there was an unconscious or subconscious realisation that no matter what their apparent acceptance, Jews never really belonged

\footnotetext{
14. Shimoni 2003: 276 .

15. Suttner 1997:3.
} 
there. ${ }^{16}$ Among historians of Jewish South Africa, only Milton Shain has been willing to state that obvious point, as evident from the titles of some of the chapters in his book on South African antisemitism - 'From pariah to parvenu', 'Shirkers and subversives' and, significantly, 'Outsiders and intruders'. ${ }^{17}$ Their whiteness was just barely salvation or redemption in a society so suffused by hate.

In a real sense, those radicals were fighting as much for their Jewish survival, for some Jewish moral commitment, as for African, Indian, or Cape Coloured liberation. Perhaps, for all their high profile and overt Jewishness, South African Jews had to prove points about themselves - in contrast to an Australian Jewry that was certainly less visible, much less 'noisy', but more secure, more certain in itself and about its place in the mainstream?

In the new South Africa, paralleling the anti-Jewish sentiments of many AfricanAmericans, there is now a rampant anti-Zionism/antisemitism from the African National Congress, some less than flattering comments from Nelson Mandela, and a variety of radical Islamic movements among the Cape Coloured people. Jews are portrayed as members of the oppressing class, a people of wealth and privilege, both there and in Israel.

\section{The Jewish tradition in Australia}

As with all racial minorities who have struggled in Western states, Aborigines and Islanders have needed help from several key sources: a sympathetic media; a parliamentary presence, however small, to press for changes within the legislative framework; a lobby and/or activist group to pressure for change; legal counsel; an economic helping hand; friends in academic places who not only research but who lend or use their work for change in the status quo; and a focus of attention and a presence in the nation's material culture.

Can we locate a political, legal, economic, cultural, academic, or even a social connection between Aborigines and Jews that is worth reporting? Which Jews, what kind of Jews, have been involved, in a serious and substantial way, and over a reasonable measure of time, in the affairs of Aborigines and Islanders? With which of the many different Aboriginal societies have they been involved?

In answer, it has to be said that Jews can be guilty of self-delusion and of distorting reality. In 1992, Evan Zuesse contended that 'Jews have continually been involved in efforts to understand and to aid in the Aboriginal struggle, far out of proportion to their overall numbers. Any significant Jewish presence at all in Aboriginal matters, of course, is already a disproportionate involvement, considering that Jews form only $0.5 \%$ of the total Australian population. ${ }^{18}$ On Tuesday evening, 27 May 1997, 13 Jewish leaders, mainly lawyers, met with six Aboriginal leaders during the Aboriginal Reconciliation Conference in Melbourne. All present wanted to foster continuing cooperation between the two communities. An ensuing press release declared that 'the stolen generation was deprived of its precious gift of inheritance'; that not to accord the Stolen Children

16. Tatz 2003: 4 .

17. Shain 1994: chs 3, 4 and 6.

18. Zuesse 1992: 16 (my italics). 
inquiry serious consideration was 'a blatant abrogation of moral responsibility'; that the 'removal of children comes within the international legal definition of genocide'; and that the Jewish community 'is concerned for the moral welfare of Australia'. Several of the Jewish team talked about the tradition of Jewish concerns for Aboriginal Australians. ${ }^{19}$

Tradition implies a strong historical foundation. And linkage. We need to examine such claims against the realities, not to mount a case for or against Jews but to understand why their contribution to Aboriginal affairs has been so disproportionately low, especially from 1900 to the 1980s.

\section{The media}

The media have been the best friends that Aborigines have, at least since the mid-1960s. Over the years, the Australian Broadcasting Corporation (Commission) ran many items on national radio, either reporting adverse conditions or recognising the need for change. ABC television, from the 1970s - particularly Four Corners and the forerunner of the 7.30 Report, This Day Tonight - was often the first to break stories about everything from the flogging of girls at Hope Vale Mission to serious problems arising from atomic weapons testing at Maralinga. No Jewish journalists, few as there were, were engaged in these broadcasts and programs.

The broadsheet press, at least in the 1970s and 80s, was more pro- than anti-Aboriginal. Again, not many Jews have been senior journalists. Over the past three decades, Michael Gawenda and Sam Lipski have written editorials or features, and Vic Alhadeff has raised Aboriginal issues in his editorship of the Australian Jewish News in Sydney. Occasionally, Aboriginal issues have been touched on by several broadsheet columnists: the late David Bornstein and Henry Mayer, and later, Elizabeth Wynhausen and Adele Horin. In the past five years, Robert Manne has had a major Aboriginal agenda, particularly on the Stolen Generation and 'the black armband' view of history. But there has been nothing like the sustained, dedicated campaigning of Jack Waterford in the Canberra Times, and Debra Jopson and Tony Stephens in the Sydney Morning Herald.

\section{The legislatures}

Our eight parliaments have had a number of Jewish members. Federal parliament has had fifteen Jews since 1901; New South Wales, 31; Victoria, 22; South Australia, seven; Western Australia, six; Queensland, four; and Tasmania, two. Four or five others may have been Jewish. Several made contributions to many public issues but not specifically to Aboriginal reforms.

Barry Cohen, in his earlier parliamentary years and as ALP Cabinet Minister under Whitlam, was concerned on several fronts, particularly on environmental matters that affected Aborigines. The most notable contributor has been Peter Baume, a very 'wet' Liberal, who was a sympathetic Minister for Aboriginal Affairs from 1980 to 1982. As has always been the case since 1969 (when Bill Wentworth became the first Minister responsible for Aboriginal Affairs), this portfolio remains outside of cabinet and is the lowliest of all ministerial portfolios on the totem pole. Baume's small ' 1 ' lib-

19. Australian Jewish News, 2 May 1997. 
eral views were never going to gain much yardage in a conservative government. Later, in 1989, he wrote a strongly worded dissenting report to the Senate Select Committee on the Administration of Aboriginal Affairs, criticising Labor Minister Gerry Hand's dealings with the Aboriginal Development Commission and his methods in establishing the Aboriginal and Torres Strait Island Commission (ATSIC).

\section{The pressure groups}

Regrettably, the era of independent pressure groups working on behalf of the Aborigines came to an end in 1972. Labor's accession to federal power promised much, and several major pressure groups - none reliant on state funding - bowed out. Politicking, such as it was and has been since then, has had to be conducted by hundreds of Aboriginal legally incorporated bodies - like the land councils, the medical and legal aid services - all of them dependent on government funding, on government registration as incorporations, and therefore either restrained or muzzled. Attacking the very source of their dependence has become a Herculean task, something the pre-1972 groups didn't have to contend with. Their problem was being tarred as socialist, or worse, communist.

To assess Jewish involvement in this politicking, we need to look, however briefly, at some of the major issues in Aboriginal history since Federation.

Establishing missions in remote parts of the continent, isolating Aborigines and Islanders both legally and geographically, was a focus during the 1900 s. The 1910 s continued a tradition of ambiguity from the colonies: assimilation as one answer, through the establishment of 'assimilation homes' like Cootamundra Girls' Home in New South Wales (NSW), and extreme segregation as another response, such as the penal settlement of Palm Island in Queensland. In the 1920s, assimilation 'havens' were established at Colebrook Girls' Home in South Australia and Kinchela Boy's Home in NSW, while massacres occurred at Forrest River Mission in Western Australia and Coniston Station in the Northern Territory. ${ }^{20}$

By the 1930s, some public concern resulted in the formation of the Australian Aborigines League (AAL) in Victoria in 1932, followed by the Aborigines Progress Association (APA) in 1937. But it was in this decade that the eugenicist fantasies of OA Neville in Western Australia, JW Bleakley in Queensland and Dr Cecil Cook in the Northern Territory flourished. These were the bureaucrats who, together with Professor Baldwin Spencer a decade earlier, saw the solution in letting the 'full-bloods' die out in inviolable reserves, pushing nice-looking 'half-caste' and 'quarter-caste' girls into marriage with white men (so that the colour gene would quickly disappear), and removing 'mixed-blood' children from natural parents to be raised in assimilation homes, to the point where, said Neville, it 'would be possible to eventually forget that there were ever any Aborigines in Australia'. ${ }^{21}$ The Australia Day Protest in Sydney on 26 January 1938 was a significant event, a day of mourning and a day on which the first major all-Aboriginal conference was held while mainstream society celebrated the landing of Captain Cook in 1788. War preoccupied the 1940s, but significant black reactions

20. All of these events are described in Horton's 1994 Encyclopaedia of Aboriginal Australia.

21. Tatz 2003: 89-92. 
were occurring in the west with the Pindan Movement, the Pilbara Aborigines who, between 1946 and 1948, went on strike for an adequate wage. ${ }^{22}$

To my knowledge, not a single Jew was involved in any of the events, protest actions, establishments, statutes, judicial or parliamentary enquiries.

An embryonic public consciousness of Aboriginal conditions was just visible in the 1950s. The National Aborigines Day Observance Committee (NADOC) was founded in 1957 to promote a day and a way of focusing mainstream attention on Aboriginal communities. ${ }^{23}$ In the same year, the Aborigines Advancement League (AAL) began operating in Melbourne as both a welfare service and a political lobby group, with Pastor Doug Nicholls as the key Aboriginal figure in the movement. Within a year, the AAL persuaded other advancement organisations, churches, and trade unions to affiliate under a federal banner, in a national body originally known as the Federal Council for Aboriginal Advancement (FCAA), later amended to include Torres Strait Islanders, and thereafter known as FCAATSI. For 21 years this body engaged in pressure politics for a better deal for Aborigines, which included federal voting rights for Aborigines and Islanders in the early 1960s, equal wages for equal work in the Northern Territory cattle industry in 1966, a referendum in 1967 to have Aborigines included in the national census, and for the Federal government to have legislative power on Aboriginal affairs (a state power in the constitution), some restitution for Aborigines caught in the Maralinga atomic testing site, better education and health, the return of the Mapoon people to the land from which they had been moved at gunpoint in 1963, and so on. There was a great deal of overlap between AAL and FCAATSI executive office-holders between 1958 and 1970, the 'golden years' of this kind of pressure group politics when perhaps more battles were won than lost.

In that time, I was an adviser to FCAATSI and the AAL (from 1961 to 1970) and represented the AAL (even though not a member) on that appalling administrative creature, the Victorian Aborigines Welfare Board, from 1965 to the end of 1967. I was, so to speak, the participant researcher. Only one Jew was active in both the AAL and FCAATSI - the late Lorna Lippman. Other Jewish members of FCAATSI were Hans Bandler - always supportive of his wife, Faith - Emil and Hannah Witton, and Len Fox, who wrote on Aborigines, on one occasion with Faith Bandler. This was the era of Aboriginal activists, the men and women who raised public awareness of the Aboriginal condition. Prominent were Joe McGinness, Faith Bandler, Charlie Perkins, Stuart Murray, Kath Walker (Oodgeroo Noonuccal), Bill Onus, Doug Nicholls, Mick Miller, and Chicka Dixon. It was also the heyday of white colleagues like Don Dunstan, Gordon Bryant, Stan Davey, Barry Pittock, Jack Horner, Alick Jackomos, Barry Christopher, Frank Engel, Doris Blackburn, and Jewish Lorna Lippman.

The Queensland government promoted a tame citizens group in 1961, One People of Australia (OPAL), as an antidote to FCAATSI. In 1963, Sydney Aborigines, tiring of some of this white-dominated advancement activity, established a self-help and service body, the Foundation for Aboriginal Affairs (FAA). No Jews were involved in either organisation.

22. Horton 1994: 868-9.

23. Now known as NAIDOC, celebrated for a week each July. 


\section{The activists}

In the late 1950s, Irene McIlwraith, a Jewish refugee from Nazi Germany in the late 1930s, campaigned strongly about discrimination and living conditions in Walgett (NSW), ${ }^{24}$ a town which began to achieve some prominence then, and which has remained as a living legacy of past policies and practices.

In 1961, a movement known as ABSCHOL (Aboriginal Scholarships) had begun in all universities. It started as a small Christian unit of the Australian Union of Students who collected funds to enable Aboriginal university attendance. Realising that teenagers were not finishing school, ABSCHOL sought funds to keep them there for as long as possible, usually by giving cash incentives to parents. The organisation soon became 'political', involving students in protests about land rights and similar issues. Federal initiatives under Labor led FCAATSI (briefly renamed at the time as the National Aboriginal and Islander Liberation Movement) to believe that they were redundant, and in 1972 the movement ended. A handful of Jewish students were involved in ABSCHOL, and two Victorian (Jewish) social workers, Phillip Boas and Colin Benjamin, were key directors.

In 1965, with the help of the Reverend Ted Noffs of the Wayside Chapel, some 30 Sydney University students, led by Charlie Perkins and Jim Spigelman (Perkins's righthand man), undertook a $3200 \mathrm{~km}$ bus tour of northern NSW towns. They 'sat-in' in protest at racial discrimination in cinemas, bars, and swimming baths. These Freedom Riders - including Spigelman, Wendy Golding, Judith Rich, and four other Jewish students - clashed, on occasion violently, with local residents, but in the longer term this remarkable event ended apartheid in the arena of social facilities.

The 1967 referendum, falsely presented and touted by the Federal government and much of the media as a 'new deal' and as 'citizenship rights' for Aborigines, was won overwhelmingly, partly because radical FCAATSI and the conservative government joined hands in promoting a yes vote. ${ }^{25}$

The mid-1960s to the early 1970s were important in Jewish community life. Dozens of Jewish students were (disproportionately) involved in New Left politics, especially at Melbourne and Monash Universities. Philip Mendes has chronicled this political activity, especially its opposition to the Vietnam War. ${ }^{26}$ I taught some of the leaders and was acquainted with several of the vibrant group who opposed not only that war but also the 1971 Springbok rugby union tour of Australia; who were involved with the anti-Israeli and antisemitic stances that arose with the Arab-Israeli war; who founded Survival magazine to combat those sentiments; and who fought antisemitism on various fronts. Tikkun olam was present in their universalism, in their rebellion against the internal Jewish community 'principle' of not getting involved 'in a form of

24. Curthoys 2002: 85-9.

25. It was in fact a clumsy attempt by Prime Minister Harold Holt to have a 'popular' question placed alongside one likely to be defeated, in this case, a question seeking approval to increase the number of House of Representatives members without a corresponding increase in the number of Senators. The Aboriginal question was heavily marketed as 'a new deal' but it was, in essence, nothing of the kind - and was overwhelmingly supported, to the extent of a 90\% 'yes' vote; the nexus question was badly defeated.

26. Mendes 1993: 143. 
ethnic politics completely unacceptable to and alien to Australian political culture' ${ }^{27}$ Yet in all this mending of the world these young people could find no place or space for Aborigines, north or south, remote, rural or urban.

Why were all these Jewish boys and girls not involved in Aboriginal matters then? Where are they now? Only two are active: Robert Manne is very much involved with Aborigines in his work on the Stolen Generation, and Ron Brunton appears to do his utmost to disparage significant Aboriginal issues such as land rights and the forcible removal of children.

Aborigines erected a Tent Embassy on the lawns outside (old) Parliament House in Canberra in 1972. (It remains in place, despite repeated political and regular police batterings and governmental decisions to cut off such services as electricity.) A stroke of genius, its message was too clever, with the great majority of Australians not reading the message that Aborigines were foreigners in Australia and were as much entitled to an embassy in the capital as any other nation. The founders were essentially the Aborigines from Sydney's FAA. No Jews were involved.

In the 1980s, no Jewish involvement was apparent in the Aboriginal movement to link up with children removed in earlier decades, nor in the Gurindji struggle for equal wages and land in the Territory, nor in the 1988 protests at the bicentenary celebrations.

\section{The lawyers}

In 2002, the Australian Jewish News, in a feature on 'Jews and Aboriginal Reconciliation', depicted Jews 'at the forefront of the battle for Aboriginal reconciliation, particularly in the legal field ${ }^{28}$ It emphasised Jewish empathy, and said a great deal about not having 'to tell Jews about human rights'; about the role of Jewish lawyers, especially the late and celebrated Ron Castan QC, in Aboriginal land rights cases; about Jews helping in the early days of the Aboriginal Legal Service in Fitzroy; about the role of the [now] NSW Chief Justice Jim Spigelman in the 1965 Freedom Rides; and the pro-Aboriginal advocacy of Justice Marcus Einfeld. In one fell swoop, this feature was, in miniature, a laudation of the Jewish-Aboriginal relationship.

In the late 1960s, a Methodist missionary from Yirrkala in the Northern Territory, Ron Croxford, came to the Centre for Research into Aboriginal Affairs (CRAA) at Monash University to consult with the late Elizabeth Eggleston, Professor Louis Waller, and me about the possibilities of pursuing Aboriginal land claims in civil court. Partly out of that advice to the group that Croxford represented came the first land claims in court, Mathaman and Others in 1969 and Milirrum $v$ Nabalco in 1971. In 1964, I had founded and was director of CRAA as a 'balance' (or complement) to the Australian Institute for Aboriginal Studies (AIAS, later AIATSIS), which had been created solely to retrieve the past but to eschew research into any 'matters affecting the contemporary life of Aborigines'. CRAA began as an applied research and action unit. Today it operates as a student service and race relations education body, as well as a research centre, re-named the Centre for Australian Indigenous Studies (CAIS).

27. Mendes 1993: 143.

28. 20 December 2002. 
The land rights era began with the significant cases mentioned above, with Justice Woodward's commission of inquiry into land rights, and with the enactment of the Aboriginal Land Rights (Northern Territory) Act in 1976. Soon after, a notorious event in Western Australia became international news when the state government, under Sir Charles Court, sent in a military-style armed convoy to ensure compliance with an order that a petroleum mining company, Amax, be permitted to drill on a known sacred site (known to contain no oil) situated on Noonkanbah, the Aboriginal-owned cattle station. In 1977, the Liberal Party did its best to disfranchise illiterate Aborigines in the West. ${ }^{29}$ Jews were not involved; nor did they protest against the 1975 decision to mine uranium in Arnhem Land, nor were they involved in the attempt by a small group of prominent Australians to lobby for a treaty with Aboriginal people. ${ }^{30}$

Only two Jews have headed parliamentary or judicial enquiries into Aboriginal matters. Justice Marcus Einfeld delivered a scathing report in 1988 on Aboriginal conditions in the border towns of Goondiwindi, Boggabilla, and Toomelah, ${ }^{31}$ and I directed a project that examined the social impact of uranium mining on Aborigines in Arnhem Land between 1978 and $19844^{32}$

Jewish lawyers Ron Castan and Jack Fajgenbaum were involved in several of the many land rights cases from the early 1990s. Justice Michael Kirby's oration for Castan in 1999 was a magnificent tribute to his work on the Mabo and Wik cases.

The four founders of the unofficial but effective Aboriginal legal aid service in Melbourne in 1964 were two Jewish academics at Monash University: Louis Waller and me, (the late) Elizabeth Eggleston, and Colin Campbell, a practising barrister in Oakleigh. After Labor won the Federal election in 1972, government-sponsored services began. It was then that Ron Castan, among others, began a remarkable career of legal engagement on the Aboriginal behalf. Several lawyers, including the late Peter Tobin and later Phillip Segal, were involved in the early years of legal aid, with Segal serving for at least two decades in western NSW. But there is simply no evidence to claim a 'tradition' and a 'continuity' of Jewish engagement, and certainly none at the Jewish institutional level.

\section{The academics}

In 1964, the federal government established the AIAS, a statutory body of 100 academics charged with 'recording the disappearing aspects of Aboriginal life before it is too late'. Of the original founding and specially appointed members, only Ruth Fink and I were Jews.

In 1966, the North Australian Workers Union (NAWU) sought to have Aborigines included in the Northern Territory (Cattle Station) Award, an agreement which left all Territory Aborigines working for about one-tenth of a white pastoral worker's wage.

The original Aboriginal Treaty Committee comprised Dr HC 'Nuggett' Coombs, Dymphna Clark, Judith Wright McKinney, Professor CD Rowley, Eva Hancock, Professor WEH

Stanner, Hugh Littlewood and Stewart Harris.

31. Einfeld 1988 .

32. Tatz 1984. 
Following intensive fieldwork, (the late) Fred Gruen - a Dunera boy - and I supplied research information to the NAWU on cattle station awards and conditions. ${ }^{33}$

Anthropologists Andrée Rosenfeld, John Bern, Ruth Fink, and David Trigger have long been associated with Aboriginal work, as 'reconstructionists' and (most of them) as activists assisting in mapping for land claims. Warren Shapiro, Fred Myers, and Faye Ginsberg, all American, have done notable work here as anthropologists. Peter Ucko and Carmel (White) Schrire (a former South African) are noted prehistorians; and Ucko, a London Jew, took AIATSIS by the scruff of its conservative neck when, as principal in the 1970s and 1980s, he turned that body's attention fully to contemporary health, education, social history, and uranium issues. Among the social psychologists, Ron Taft coauthored a book on race attitudes in the 1970s. ${ }^{34}$ The historian-archivist, Peter Biskup, published an important work in 1973, Not Slaves, Not Citizens. ${ }^{35}$ Medical scholars have been surprisingly few, with Max Kamien's work on The Dark People of Bourke the one significant analysis. ${ }^{36}$ Social scientist Andrew Markus has, since 1990, written works on Australian race relations, the 1967 referendum, and on the struggle for Aboriginal rights. Historian Paul Bartrop has incorporated Aboriginal issues in his eclectic work. Anthropologist Jon Altman (Israeli born, New Zealand educated) has made Aborigines in the economy his special field. Linda Briskman has recently published The Black Grapevine, a significant contribution from a social work specialist to the literature on the Stolen Generations. ${ }^{37}$

\section{The business community}

Jews have been essentially metropolitan people. There was some rural experience when World War II refugees were allowed into Australia on condition that they resided in rural towns for a period. In the northern tablelands of NSW, a few properties were owned or leased by Jews and there are several Aboriginal Cohens in the north, with such 'Christian' names as Esther and Jacob, doubtless a legacy of the tradition by which menial Aboriginal staff were 'given' the owner's or the property's name.

The urban relationship has been as rare, with many, if not most, Jews never meeting, let alone employing, Aborigines. There has never been occasion for economic or labour competition, as in the United States, and there has been no significant Aboriginal tenancy of Jewish-owned apartments.

Jewish philanthropy has only rarely (and only recently) stretched to Aboriginal enterprises or institutions. The Rona Tranby Project, an important and recent gift, assists in the recording of Aboriginal oral history.

\section{The writers and artists}

I dwell a little on a few Jewish writers and painters because they both capture and convey images and emotions better than most.

33. Sharp and Tatz 1966: 197-215 and Gruen 1966.

34. Taft et al. 1970.

35. Biskup 1973.

36. Kamien 1978.

37. Briskman 2003. 


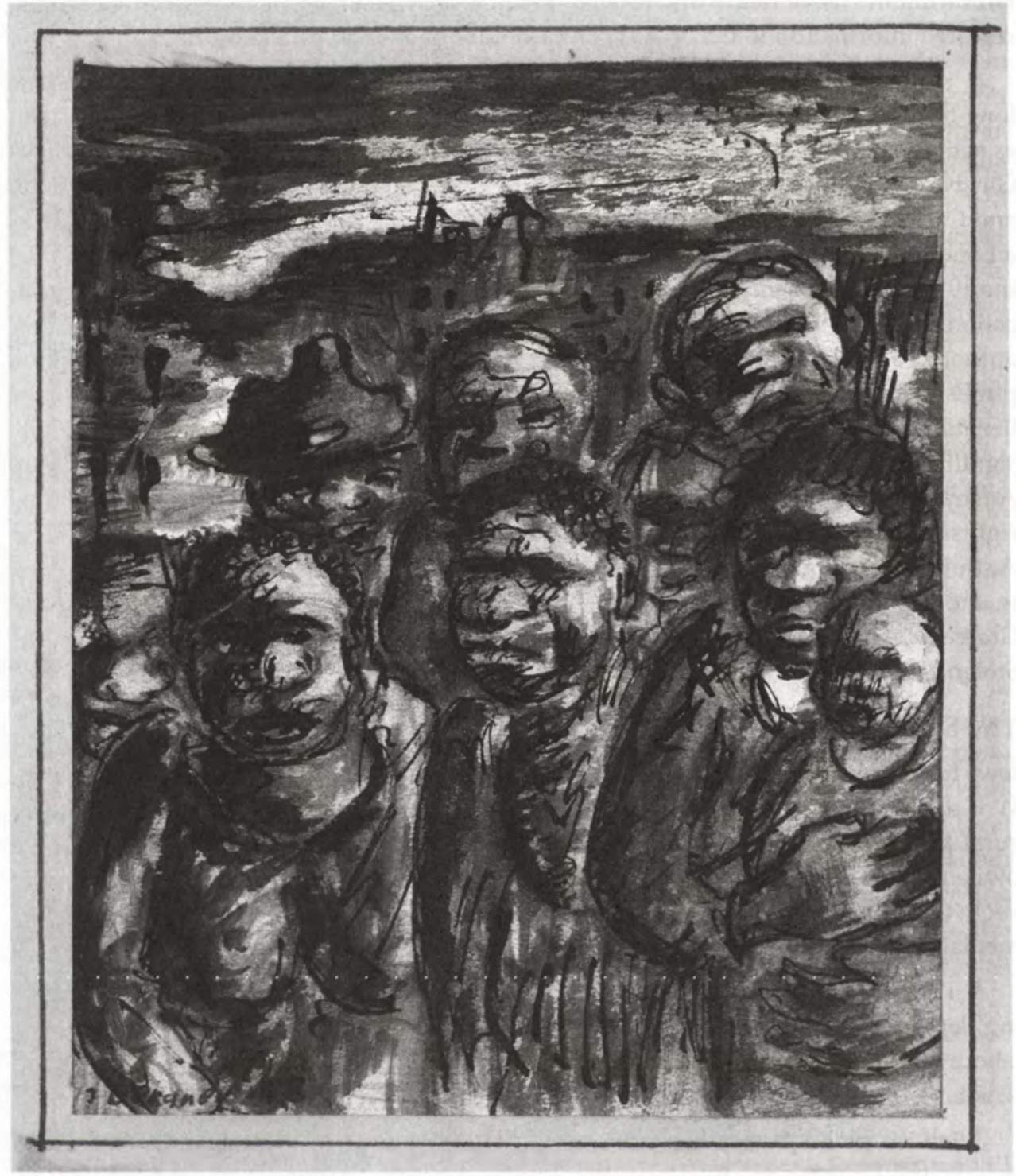

Yosl Bergner. Born in Austria 1920, worked in Australia 1937-1950, currently lives and works in Israel. Group of Aborigines 1938, Pen \& ink, brush, gouche, $10.8 \times 9.0 \mathrm{~cm}$. Gift of Mrs Bergner, 1984, National Gallery of Victoria, Melbourne. Reproduced with the permission of the artist.

In 1921, Peretz Hirschbein, the famed Yiddish novelist and dramatist, visited Sydney and Melbourne. He was stunned by the White Australia outlook, the brutality of attitudes to Aborigines and their landlessness, and by the trauma and sadness in those Aborigines he met. Certainly, he wrote, this land would have had more appeal for him 'if the 60,000 native born children of the land would have had their place, as was their right'. From what he'd been told, 'in no other young country have the indigenous people been so brutally treated by whites'. ${ }^{38}$ 
Another Jewish-Aboriginal connection dates back to the noted English writer on London Jewry, Israel Zangwill, who broke with Zionism in the 1920s and founded the Jewish Territorial Organisation - to create a Jewish homeland, wherever possible, outside of Palestine (a place deemed too difficult and too bitter to contemplate). In the 1930s, the Melbourne philanthropist Isaac Jacobs espoused Zangwill's Territorial cause, seeking approval for a kibbutz of 800 German and Austrian Jewish refugees in South Australia, an idea supported by the state premier but vetoed by the Federal government. However, there was no consultation with, or discussion about, Aborigines.

The London-based Freeland League, established in 1935, wanted to buy 7 million acres in the East Kimberleys, to support at least 50,000 Jews. Dr Itzhak Nahman Steinberg - the first People's Commissar for Justice after the Russian Revolution, but soon after a refugee from Lenin - arrived in Australia in 1936 to pursue this dream. The Kimberley scheme was well supported by the Australian Council of Trade Unions, the NSW Labour Council, and the Perth unions. Churches offered support, as did the Western Australian premier. The Canberra Times, the Age, and the Sydney Morning Herald opposed what the Australian Worker supported, namely, 'a generous working class contribution toward the solution of the terrible refugee problem', a 'haven for the victims of fascist ferocity ${ }^{39}$ Again, there was no concern for the lands occupied by Aborigines or for Aboriginal viewpoints - only the usual stereotyping and their diminution as people.

In 1933, another Jew arrived to promote a Jewish resettlement scheme in the Northern Territory. Melekh Ravich, renowned Yiddish poet, writer, and critic, was the father of the artist Yosl Bergner. In 1937, JNL Kadimah published Melekh's essay 'Northern Territory Journey, 1933' ${ }^{40}$ 'The blacks in Australia cannot be regarded as the owners of the land', he wrote, because 'they belong to the very lowest level of civilization.' Amid much talk of wild, unmusical, frightening, opium-loving, and prostituting people, their future lay in being allotted 'several thousand square miles of land' where they could be taught 'to plough and sow, and thus the Aboriginal issue would be solved'. However, in Arnold Zable's account of Ravich, he shows the poet's compassion and liking for the Aborigines he worked and rode with in the Territory. ${ }^{41}$

Melekh's younger brother, Herz Bergner, wrote several novels, including Light and Shadow, in which we see some empathy for the outcast Aborigines. Yosl Bergner, born in Vienna but raised in Warsaw, came to Melbourne as a 17-year-old in 1937. Melekh had earlier brought photos of Aborigines from his Territory visit. To Yosl, 'they looked exactly like Jews, dispossessed people'. Yosl lived and worked in Melbourne, in textiles, at the markets, and in that Melbourne Depression he 'saw Warsaw with its poverty'. He befriended Judah Waten, the novelist and short story writer who had come to Perth from Odessa in 1914. 'Everything I paint', said Yosl, 'has an element of displacement. ${ }^{42}$ Yosl and his artistic colleagues were interit not only on social realism but 'with a concern for social injustice, with a fight for liberty and life against tyranny

38. Personal communication from Arnold Zable, translator of Hirschbein's journals.

39. Casey 2002.

40. Ravich 1992: 33-7.

41. Zable 2002: 195-6.

42. Graham 1986 (Ronin Films). 


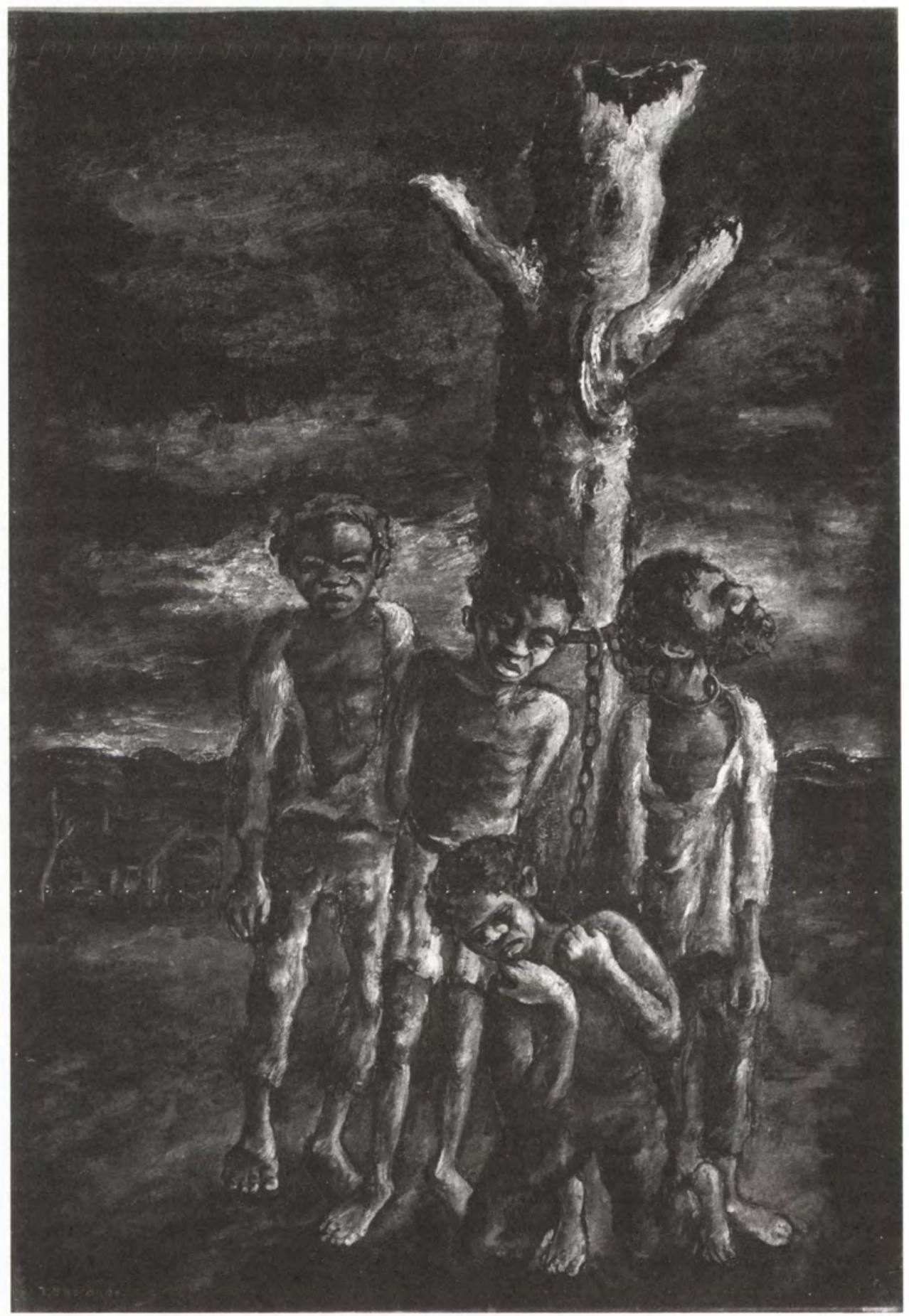

Yosl Bergner. Born in Austria 1920, worked in Australia 1937-1950, currently lives and works in Israel. Prisoners 1944. Oil on composition board, $94.2 \times 63.8 \mathrm{~cm}$. Gift of the artist, 1979. National Gallery of Victoria, Melbourne. Reproduced with the permission of the artist. 
and reaction'. And so he painted Aboriginal scenes against a background 'with what I imagined was happening in Poland'. His canvases carried titles such as 'Village on Fire', 'Looking Over the Ghetto Wall', 'Fathers and Sons', the latter a portrait of depressed loneliness, of the Jewish/Aboriginal father who cannot protect his sons.

Yosl joined the Australian Labour Company because, being an alien, he was ineligible for the regular army. He was stationed at Tocumwal, on the New South WalesVictoria border of the River Murray. There he painted 'Tocumwal Camp', and later, at the significant Anti-Fascist Art Exhibition in Melbourne in 1942, he presented poignant and powerful works titled 'Aboriginal Man' and 'Two Women'. A later painting, 'Prisoners' created a stir: it showed Aboriginal station workers, striking for higher wages, chained to a tree. It was based on a photograph he had seen of a Western Australian arrest (doubtless a reference to police harassment of the Pindan Group, referred to earlier). Another powerful image was 'Aborigines are Coming to Town', town being Melbourne, a place decreed out of bounds to most rural black people at that time. 'Attitudes were very, very rough, unjust, you know', he said. At this point, he believed that he beheld two people of two very different cultures now unified; he kept comparing Polish ghetto Jews to the Aborigines he was seeing in country Victoria and NSW.

Apart from the federal politicians and city editors, there was one vociferous Australian critic of the Kimberley/Northern Territory proposal - AP Elkin, professor of anthropology at Sydney University and, in that era, the only torch-bearer (with his bete noire, Professor Donald Thomson) for the Aboriginal cause. Despite, or in spite of, a Jewish paternal grandfather, Rabbi Moses Elkin, grandson Adolphus was an austere, severe, imperious, ordained Anglican. ${ }^{43}$ He objected strongly to this Jewish presence (much more so than to any other 'white' presence), fearing its impact on Kimberley Aboriginal life and culture. Curtin's Labor government vetoed the Jewish Kimberley scheme in 1944.

Judah Waten, the indomitable communist, was a poet, novelist, and short-story writer. His story collection, Alien Son, has become a classic in Australian literature. ${ }^{44}$ Waten influenced Bergner on many issues, possibly on Aboriginal matters, but his stories are essentially the experiences of Jewish migrant families in Australia. 'Black Girl' tells of Lily Samuels (the choice of surname was no doubt deliberate) who lived in 'a derelict place because they were unable to find accommodation in any other part of the city and because they were aborigines'. It is a poignant and compelling story of black-white relationships, and of white sexual attitudes to 'girls of colour'.

Born in Hungary in 1915, David Martin was a successful and admired poet and novelist who came to Australia as an adult in 1949. For a while he lived in a bush town where his wife was the schoolteacher. His children's novel, Hughie, told the story of an Aboriginal boy in such a place. I have found only one poem by Martin on an Aboriginal theme, 'Mission Station, North Queensland', written between 1953 and 1955. It captures the appalling attitudes and conditions prevailing then: ${ }^{45}$

Yes, they mean well. They love the Simple Black.

(I love my cat, that wayward little creature!)

\footnotetext{
43. Wise 1985

44. Waten 1952

45. Martin, no date.
} 
With humble pride they point to every feature:

Drainage is good. We're pulling down the shack.

We've stamped out hook-worm, promiscuity,

And would do more, but ... such a shiftless pack.

But that was all. In the field of Australian literature, one looks for Jewish writers on Aboriginal themes: but none leap, let alone peep, out of several anthologies. ${ }^{46}$ In editing Shalom, Nancy Keesing pointed out 'that there are not, and never have been, many Australian Jewish writers of fiction'. Where Jews and Aborigines do interact in a compelling way is in the works of two non-Jewish writers, Patrick White's Riders in the Chariot (1961) and Xavier Herbert's Poor Fellow My Country (1975), a subject dealt with at some length by Healy (1989). ${ }^{47}$

Fay Zwicky, noted poet, teacher, and critic, comes closest to explaining the silence of the Australian-born Jewish writer. ${ }^{48}$ She talks of 'democratic repression', the bland Anglo-Saxon context, 'the babble of speech masking a dumb void', 'a landscape without a human being in it'. It was reading the confident, assertive Jewish-American novelists like Bernard Malamud, Saul Bellow, and Phillip Roth, that helped her articulate an awareness of self and helped her overcome uncertainty about her own Jewish identity and its meanings. 'To have compulsions in the Anglo-Saxon world ... is to be marked out as a freak, an alien and unwanted voice'. It was the 'probing Quixotic honesty' of the American Jewish writer that enabled her to find her own voice 'and the courage to speak'.

Of the 80 authors ${ }^{49}$ presented in three Australian-Jewish writer anthologies, only Andrea Goldsmith addresses Aborigines in general and my questions in particular. This fifth-generation Australian describes her search not so much for identity as for certainty. ${ }^{50}$ In this journey, she finds Jewishness in books and in texts rather than in people or prayer: 'My Jewishness I have found in books, my Australian-ness, when it existed at all, was little more than a whiff of eucalyptus.' But she seems never to have been moved by the daily doses of Aboriginal highs and lows in the major newspapers, on radio or television, by the often appalling events in local Fitzroy, Framlingham, or Lake Tyers. Only when she visited Uluru, Kata Tjuta, and Kings Canyon in the Northern Territory - the great symbols of traditional Aborigines - was she able to ask the key question:

I've never before felt my white Australianness so strenuously and I've never wanted it less. Why, I wonder, when I have identified so closely with other outsiders, have I not with Aboriginal Australians?

Goldsmith doesn't answer her question, but at least she wonders.

Since 1988, Arnold Zable has been engaged in matters Aboriginal, writing in newspapers and in his short stories, at times reflecting on the parallel voyages of Jews and Aborigines in search of memory and place. He has assisted the Wurundjeri people

46. Keesing 1978, Hammer 1988, Jacobs 1999.

47. Healy 1989: 273-9.

48. Zwicky 1986: 91-102.

49. The Hammer 1988 book (Pomegranates) has inflated the number of writers by collecting just about anything and everything written by Jews, even by non-Jews on Jewish themes. The Keesing 1978 and Jacobs 1999 books at least present accomplished and recognised authors.

50. Goldsmith 1999: 3-17. 
of Victoria in recording their history, and produced a CD-ROM, with Wurundjeri elders, detailing a history of Melbourne's Aboriginal peoples. His elder brother, Benny, has been active as friend and artist in Aboriginal communities for many years. The Zables come from the same Polish, socialist, radical, Yiddish-speaking line as the Bergners and Ravich, with a world outlook very different from that of the assimilationist German and Anglo-Jews in Australia.

\section{The dearth and the disappointment}

Since the Jewish record is, indeed, thin - and let me say, in conclusion, that it verges on the anorexic - there must be some explanation, particularly when the Australian record is compared with Jewish participation abroad.

One can speculate on the reasons. First, Jewish settlement from 1788 never impinged on, nor was juxtaposed physically with, Aborigines. ${ }^{51}$ In both America and South Africa, Jews and blacks have always been interwoven and interconnected, while most Australian Jews have been able to live a lifetime without encountering an Aborigine or Islander in the flesh.

Second, many Jewish communities need to be 'expediential', to ascertain just what is or isn't good for Jews and to act accordingly. Their very marginality, which makes for this kind of protective behaviour, in turn makes for an empathy with other marginalised peoples, as shown in some strong Jewish activism in the United States and South Africa. The record of 'official' Australian Jewry, apart from a very small group of diverse individuals, shows a sustained expedience, a reluctance to get involved in contentious issues generally, let alone those affecting other marginalised peoples. The question is whether Australian Jewry needed to be as expedient as the South Africans.

Third, the Jewish struggle for recognition of religion, which came readily enough, was not comparable to the black experience of seeking 'human-ness' and freedom from physical fear.

Fourth, there was never any labour or occupational conflict, let alone business competition.

Fifth, pre-war Australians had no demonstrable interest in anything Aboriginal. Dying out, or extreme segregation, or social and economic assimilation for 'half-castes' in urban areas was their destiny. Apart from a handful of bureaucratic eugenicists, a squadron of remote missionaries, three or four anthropologists, perhaps two journalists, one or two literary voices, and a small clutch of painters, no one expressed any interest in Aborigines, and certainly not in Islanders.

Compared with the United States and South Africa, no raging social or political dynamic cried out for change. There were no observable strikes on cattle or sheep properties. (There were, but since these disruptions didn't take the traditional form of strike, with slogans and placards, no one recognised them for what they were.) No unions, militant or otherwise, worked on behalf of Aborigines. To the contrary, the unions opposed Aboriginal economic or wage progress at every turn. The left wing of politics,

51. Bartrop 1997: 23-37. 
socialist or communist, was virtually mute on Aborigines. Why, then, should Jews have been visible, active or audible?

Sixth, it has been suggested that perhaps Jews relate only to minorities who share an experiential struggle for civil rights, as with black South Africans and Americans, and that Jews somehow have not related, or do not, relate to hunter-gatherer societies. There is, indeed, a veritable galaxy of Jewish anthropologists concerned in, and with, San Bushmen, Canadian and American First Nations people, and the Inuit. ${ }^{52}$ These scholars have had to battle more than vicious Jim Crow laws in American and South African legislatures. They have struggled in the more difficult ideological ring, fighting against the 'scientific racists' who constantly seek out the ineradicable racial gene that justifies the hierarchy of the races, the superior 'white race', the corrupting 'Jewish race', the inferior 'black race', the 'primitive aboriginal races'.

Finally, Jews in Australian academe are no longer a rare species, but they were thin on the ground in the first three decades after World War II. Those in university life tend to be in the professional fields of law, medicine, engineering, and architecture. Those few Jews who have entered the arts and social sciences and who have had 'compulsions' (as Zwicky calls them), who have cared, or cared enough, to work in what 'tradition' calls 'the struggle', are few in number.

So much for possible explanation. But reality is the issue. In the 1950s, the Jewish Council to Combat Fascism and Antisemitism passed supportive resolutions, as did the Jewish Democratic Society and the Sydney Jewish Left in the 1980s. My contention about dearth rests on the absence of any sustained engagement and action, not on the presence of resolutions, of gestures or symbols of support, however well meant. To my knowledge, these organisations did not provide money or manpower. ${ }^{53}$

Changes have occurred on many fronts these past two decades and more Jewish interest has surfaced. Some of it is in the form of anti-racism programs, such as those established by the Albert Dreyfus unit of B'nai B'rith, the Anti-Defamation Commission of B'nai B'rith, and the Jewish Holocaust Centre in Melbourne. Well-intentioned, they have yet to be tried, tested, evaluated. ${ }^{54}$ Much of present community action remains at the level of 'multicultural' events, somewhat shy and hesitant 'matzo ball-bush tucker' lunch meetings of the cultures. In 1994, an important article appeared in the now defunct quarterly journal, Australian Jewish Democrat - Peter Wertheim's 'A Jew-

52. One can begin with the illustrious German, Franz Boas, the legendary Belgian, Claude LeviStrauss, and continue with Sol Tax, Max Gluckman, Meyer Fortes, through to Richard Lee, Harvey Feit, Michael Asch, Phillip Tobias, among many others, and end with the incomparable Hugh Brody.

53. In all my years of intimate contact with the AAL and FCAATSI, from 1961 until 1971, I saw no visible sign of support from Jewish organisations, official or Left-inclined. Faith Bandler has several tales to tell about the absence of Jewish support.

54. In the mid-1970s I conducted 'race relations' education programs in the Bachelor of Education curriculum at the Armidale Teachers College and the University of New England. After some five years of trials, using, in the main, prominent Aboriginal intellectuals and artists as educators, and two years' full-time evaluation of their effectiveness, the net result was that the 'good attitudes' developed in the program soon enough 'switched' when teachers were pitched into actual teaching situations in outback towns. The town's culture overwhelmed them. Nothing has changed in 30 years, and I remain sceptical of such efforts. 
ish perspective on social justice' - in which he argued the case for Jewish advocacy on Aboriginal issues. ${ }^{55}$ Several symposia have been organised by Jews anxious to know 'what can we do?' and 'how can we contribute?' At an evening of this kind in Sydney in 2003, Pat O'Shane told the large Jewish audience to hang its head in shame at its record of support for Aborigines. ${ }^{56}$

A few Aboriginal scholars have shown an interest in Jewish life and history, one or two in a hostile way, seeing the Palestinian plight as their more appropriate metaphor. ${ }^{57}$ The alleged similarities and empathic aspects of Jewish-Aboriginal religiohistory have not attracted scholars from either side.

Most of the many Jewish audiences I address still react in the manner of non-Jewish audiences. They are usually hostile as they question expenditure on Aborigines, when they disparage all land rights claims, when they blame Aborigines alone for all the physical, social, health, and economic ills that beset them. I always hope that Jews will have moral insight and outlook; the fact that they don't continues to disappoint.

Unlike the United States and South Africa, there is, as yet, no Islamic movement that has attracted diverse Aboriginal communities. There is no vicious anti-Israel and anti-Jewish rhetoric, let alone physical abuse of Jews or their property. Unlike the black peoples of the United States and South Africa, there is no obvious reason for Aborigines to have any hostility towards a people they almost never meet, nor work with, nor visit socially, nor play games with, nor borrow money from, nor whose apartments they rent. Aborigines have rarely been subjected to the centuries-long tradition of Christian antisemitism and have no millennium-long baggage of contempt for Jews. In turn, one has to say that Aboriginal communities and organisations have not targeted Jewish institutions or philanthropists for support.

Some Jews, sometimes many Jews, have opposed racial injustice in the United States and South Africa. Some have raged against it, fought it, gone to jail for it, even died for it. They have been both revered and excoriated by fellow Jews for their value stance. What little passion or commitment there has been in Aboriginal affairs has come largely from those born outside Australia, from those like Yosl Bergner, who were sensitised to insight by the experiences of their own immediate environs at their point of emigration. When Bergner saw Fitzroy and Tocumwal, he saw Warsaw.

In the end, one has to be both disappointed and perhaps uncomplimentary. Unlike South Africa and the United States, there has been no violent race politics in Australia. Activists and supporters have had no need to fear a Mayor Daley in Chicago or a terroristic secret police force in Pretoria. There was never a life and death struggle, a life and detention struggle, as with Ruth First and her 117 days in solitary confinement, her death by postal bomb. In a climate of peaceful politics, and for the most, in a climate of polite politics, there could, and should, have been more interest and more activism by Australian Jews, not less.

\footnotetext{
55. Wertheim 1994: 10-14.

56. Australian Jewish News, 15 August 2003.

57. Shtargot 1993: 10-11.
} 


\section{Acknowledgements}

My thanks to Lynley Wallis, Sandra Tatz and Arnold Zable for their editorial comments.

\section{References}

Bartrop, Paul 1997, 'Divergent experiences on the frontier: Jews and Aborigines in early colonial Australia', Australian Jewish Historical Society Journal XIV: 23-37.

Biskup, Peter 1973, Not slaves, not citizens, University of Queensland Press, St Lucia.

Briskman, Linda 2003, The Black grapevine: Aboriginal activism and the stolen generations, Federation Press, Sydney.

Brockman, Norman (ed) 1994, An African biographical dictionary, Santa Barbara, California.

Bunting, Brian 1964, The rise of the South African Reich, Penguin African Library, London.

Casey, Andrew 2002, 'The un-Promised Land', Workers Online, International (www), issue 136.

Cohen, Percy 1980, Jewish radicals and radical Jews, Institute of Jewish Affairs and Academic Press, London.

Curthoys, Ann 2002, Freedom ride: a freedom rider remembers, Allen \& Unwin, Sydney.

Einfeld, Justice Marcus 1988, Inquiry into the social and material needs of the New South Wales-Queensland border towns of Goondiwindi, Boggabilla and Toomelah, 1987-88, Human Rights and Equal Opportunity Commission, Sydney.

Goldsmith, Andrea 1999, 'Only connect: musings of an Australian Jew', in Alan Jacobs (ed) Enough already: an anthology of Australian-Jewish writing, Allen \& Unwin, Sydney: 3-17.

Gondarra, Djiniyini 1992, 'Through similar journeys comes revelation', Generation 3(1) April: 20-3.

Graham, Trevor (director) 1986, 'Painting the town: a film about Yosl Bergner', video, Ronin Films, Victoria.

Gruen, Fred 1966, 'Aborigines in the Northern Territory cattle industry - an economist's view' in Ian Sharp \& Colin Tatz (eds) Aborigines in the economy, Jacaranda Press, Brisbane: 197-215.

Hammer, Gael (ed) 1988, Pomegranates: a century of Jewish Australian writing, Millennium, Sydney.

Healy, J] 1989, Literature and the Aborigine in Australia, University of Queensland Press, St Lucia.

Horton, David (ed) 1994, The encyclopaedia of Aboriginal Australia: Aboriginal and Torres Strait Islander history, society and culture, Aboriginal Studies Press, Canberra.

Huddleston, Trevor 1956, Naught for your comfort: a South African testimony of hope, Doubleday.

Jacobs, Alan (ed) 1999, Enough already: an anthology of Australian-Jewish writing, Allen and Unwin, Sydney.

Kamien, Max 1978, The dark people of Bourke: a study of planned social change, Australian Institute of Aboriginal and Torres Strait Islander Studies, Canberra. 
Katz, Shlomo (ed) 1969, Negro and Jew: an encounter in America, The Macmillan Company, London.

Keesing, Nancy (ed) 1978, Shalom: Australian Jewish stories, Collins, Sydney.

Mandela, Nelson 2002, Long walk to freedom, Abacus, London.

Martin, David, no date, Poems of David Martin 1938-1958, Edwards and Shaw, Sydney.

Mendes, Philip 1993, The new Left, the Jews and the Vietnam War 1965-1972, Lazare Press, Melbourne.

Ravich, Melekh 1992, 'Northern Territory journey, 1933', Generation 3(1) April: 33-7.

Reeves, Ambrose 1960, Shooting at Sharpeville: the agony of South Africa, Victor Gollancz, London.

Shain, Milton 1994, The roots of antisemitism in South Africa, Witwatersrand University Press, Johannesburg.

Sharp, IG and CM Tatz 1966, Aborigines in the economy, Jacaranda Press, Brisbane.

Shimoni, Gideon 2003, Community and conscience: the Jews in Apartheid South Africa, University Press of New England, Hanover.

Shtargot, Alex 1993, 'An interview with Gary Foley', Australian Jewish Democrat 4(3) Spring: 10-11.

Suttner, Immanuel 1997, Cutting through the mountain: interviews with South African Jewish activists, Viking, London.

Taft, Ronald, John Lawson and Pamela Beasley 1970, Aborigines in Australian society: attitudes and social conditions, Australian National University Press, Canberra.

Tatz, Colin 1979, Race politics in Australia, University of New England, Armidale.

- 1984, Social impact of uranium mining, Report for Minister of Aboriginal Affairs, 1978-84, Australian Institute for Aboriginal and Torres Strait Islander Studies, Canberra.

- 2003, With intent to destroy: reflecting on genocide, Verso, London.

Waten, Judah 1952, Alien son, Angus and Robertson, North Ryde.

Wertheim, Peter 1994, 'A Jewish perspective on social justice', Australian Jewish Democrat 4(3) Winter: 10-14.

Wise, Tigger 1985, The self-made anthropologist: a life of AP Elkin, Geo. Allen and Unwin, Sydney.

Zable, Arnold 2002, 'Between sea and sky' in The fig tree, Text Publishing, Melbourne: 189-216.

Zuesse, Evan 1992, 'Jews and Aborigines: a shared universe', Generation 3(1) April: 1116.

Zwicky, Fay 1986, 'Democratic repression: the ethnic strain' in The lyre in the pawnshop: essays on literature and survival 1974-1984, University of Western Australia Press, Perth: 91-102. 